\title{
Bursa Şairlerinin Vefeyatnamesi
}

Fatma S. KUTLAR*

Divan edebiyatı alanındaki araştırmalar, genellikle, Arap alfabesiyle yazılmış eserlerin yazı çevriminin yapılmasına ve hazırlanan metinlerin birbirine çok benzeyen bir plân dahilinde incelenmesine yöneliktir. Son yıllarda, böyle çalışmaları hedef alan eleştirilerin çoğalması, kimi araştırmacıları farklı konularla ilgilenmeye yöneltmiş görünmektedir. Bu doğrultuda, şehirlerin yetiştirdiği şairlere ilişkin incelemelerin yapıldığı da dikkati çekmektedir. Şairleri, mensup oldukları şehirleri çıkış noktası alarak yapılan çalışmalardan biri Doğu Akdeniz Üniversitesi öğretim üyelerinden Kadir Atlansoy'a aittir. Atlansoy, Bursa Sairleri, Bursa Vefeyatnamelerindeki Şairlerin Biyografileri, Asa Kitabevi, Bursa, 1998 adlı kitabını, Bursalı şairlerin biyografilerini Bursa vefeyatnamelerine bağlı olarak ortaya koymak, edebiyat tarihine kaynaklık eden eserleri taramak suretiyle Bursa'da yaşamış veya yetişmiş şairlerin isimlerini belirlemek ve yer aldıkları kaynakları tanıtmak amacıyla hazırlamış̦tır.

Kitap, Ön söz, Kısaltmalar ve Giriş ten sonra Klâsik Türk Edebiyatı Tarihinin Kaynaklarındaki Bursa'yla İlgili Şairler, Bursa Vefeyatnameleri, Bursa Vefeyatnamelerindeki Şairler başlıklı üç bölüme ayrılmaktadır. Sonuç ve Bibliyografyayı beş vefeyatnamenin yazı çevriminin verildiği Bursa Vefeyatnamelerindeki Sairlerin Biyografileri takip etmektedir. Eserin sonunda, Sairler İndeksi ve EK İsmâil Beliğ Efendi'nin Güldeste-i Riyâz-ı İrfân'ından başlığı altında Arap harfli metnin Gülbün-i Rabi'-Hamis bölümünün fotokopisi yer almaktadır.

\footnotetext{
'Hacettepe Üniversitesi Öğretim Uyesi.
} 
Ön sözde, Bursa şehri üzerine kaleme alınmış bir şuara tezkiresi bulunmadığına dikkati çeken Atlansoy, Bursa'nın İstanbul'dan sonra en çok şair yetiştiren şehir olduğunu ortaya koymak ve son yıllarda önemi giderek artan şehir müesseseleri tarihi araştırmalarına da katkıda bulunmak için edebiyat tarihçisi gözüyle vefeyatnameleri taradığını belirtmiştir (s. 10). Çalışmanın, I. Şehir ve Kültür (s. 17-18), II. Kültür Tarihinde Bursa'nın Yeri (s. 18-33) alt başlıklarını taşıyan girişinde, ana çizgileriyle, Bursa'nın çeşitli yüzyıllar içindeki gelişimine, kurumlarına ve yetiştirdiği önemli kişilere değinilmiştir. Klâsik Türk Edebiyatı Kaynaklarındaki Bursa'yla İlgili Şairler (s.37-73) başlıklı birinci bölüm, İslâm etkisi taşıyan Türk edebiyatının yazılı kaynaklan hakkındaki bilgilerle başlamaktadır. Ana bașlık, I. İslâm Kültürründe Tarih Yazıcılı̆̆ı, II. Osmanlı Tarih Yazıcılı̆̆, III. Tarih ve Biyografi, IV. Türk Suara Tezkireleri, V. Diğer Kaynaklardaki Bursa ile İlgili Şairler olmak üzere beş alt başlıkta irdelenmektedir. Osmanlı devletinin kuruluşundan başlayarak günümüze kadar ulaşan tarih eserlerinin de ana çizgileriyle ele alındığı bu kısımda, tarih ve biyografı ilişkisine değinilmekte, bu ilişki Türk şuara tezkirelerine bağlanarak tezkire türü ve kökenleri üzerinde durulmaktadır. Takiben, Türk şuara tezkireleri kronolojik olarak ele alınmakta ve yirmi iki tezkiredeki şairlerden Bursa'yla ilgisi olanlar -mahlâsları, lâkapları, isimleri, doğum veya ölüm tarihleriyle birlikte- sıralanmaktadır. Birinci bölümün sonunda, konuyla doğrudan ilgili olan birkaç esere kısaca temas edilmekte ve Türk Suara Tezkirelerindeki Bursa ile IIgili Sairler başlığı altında 169 şairin adı alfabetik olarak verilmektedir.

Kitabın Bursa Vefeyatnameleri başlıklı ikinci bölümünde önce vefeyatnameler hakkında genel bilgiler verilmiştir. Bursa vefeyatnamelerine gelinceye kadar benzeri veya aynı türdeki eserlere ve bunların ilim, kültür ve sanat tarihi bakımından önemine değinilmiştir. “...Bazı vefeyatnamelerde şehrin tabiî güzelliklerini, mesire yerlerini, önemli eserlerini ve belli başlı sularını anlatan bölümlere yer verildiğini..." (s. 79) belirten Atlansoy, vefeyatnamelerin bu yönünü, Lâmiî Çelebi'nin Şehrengiz-i 
Bursa'sında Bursa şehrinden ve güzelliklerinden söz etme özelliğine benzetmiştir. Şehrengiz-i Bursa'yı da “...Bursa vefeyatnamelerinin müjdeleyicisi ve öncüsü saymak mümkündür" (s. 78-79) gibi bir görüş ileri sürmüştür. Biz, türler arasında görülen benzerliklerden hareket ederek birini diğerinin öncüsü sayma konusunda ihtiyatlı olmak gerektiğini düşündüğümüzü de ekleyelim. Daha sonra, sayıları yirmiyi aşan vefeyatnamelerin yarıya yakınının Bursa'yı mihver aldığı üzerinde de durulmuş ve Bursa vefeyatnamelerinin on ikisi, yazar ve eser adı ile telif tarihi verilerek kronolojik olarak sıralanmıştır. Bunlardan Sehmî Mehmed'e ait vefeyatnamenin ve dipnotta şair Rakım'ın Kadılar isimli aynı türdeki eserinin ele geçmediğine değinilmiștir (s. 80). On iki vefeyatnameden dokuzu -yazarı ve yazarın diğer eserleri hakkında verilen genel bilgilerle birlikte- tespit edilen nüshaları, adları, yazılış sebepleri ve yazılış tarihleriyle tanıtılmıștır. Adı sıralanan on iki eserden on birinin mevcudiyetinden bahseden yazarın niçin sadece dokuzunu tanıttığına dair bölümün girişinde herhangi bir bilgi bulunmamaktadır. Hulasatü'l-Vefeyat ın çalışmaya dahil edilmeme sebebine 276. dipnotta; Mehmed bin Sadî'nin Vefeyatnamésine yer verilmeme sebebine ise üçüncü bölümde (s. 124) değinilmektedir. Oysa bunların ilgili bölümün başında bir arada yer alması uygun olurdu. Ayrıca, vefeyatnamelerin yararlanılan nüshaları için kullanılan kısaltmalar ilgili nüshanın yanına yazılırken, Beliğ İsmail'in Güldeste-i Riyaz-ı İrfan ve VefeyatI Danişveran-ı Nadiredan'ı için kullanılan kısaltmalar verilmemiştir.

Çalışmanın, Bursa Vefeyatnamelerindeki Sairler başlıklı üçüncü bölümüne, vefeyatnamelerin kültür tarihinin yanı sıra edebiyat tarihi için de önemli olduğu belirtilerek girilmekte ve vefeyatnamelerin iki koldan geliştikleri söylenerek kaynaklar tasnif edilmektedir. Sekiz vefeyatnamede yer alan șairler, yazarının atıfta bulunduğu kaynaklardan da söz edilerek, sıralanmaktadır. Fakat bu stralamalarda, Bursa Vefeyatnamelerindeki Sairlerin Biyografileri başlıklı bölümle karşılaştırıldığında, bazı şair adlarının eksik olduğu, bazı şair adlarının da farklılıklar gösterdiği görülmektedir. Bunlardan

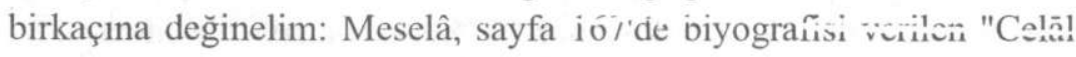


Efendi" 127. sayfadaki tabloda yer almazken, 211. sayfadaki "Bādıncāni-zāde 'Abdu'llāh Efendi”, 217. sayfadaki “Cem", 221. sayfadaki "Cināni”, 226. sayfadaki "Cünūnī", 235. sayfadaki "Ġanī" ve 256. sayfadaki "Kādirī”nin adlan ise 129. ve 130. sayfadaki listede bulunmamaktadır. 133. sayfada hakkında "R. Muflihun'da biyografilerine yer verilen şairler şunlardır:" denilerek on şairin adı sıralanmakta, arkadaki metinde (s. 365-367) şair sayısının niçin üçe indiğine dair bir açıklama yapılmamaktadır. 133. sayfadaki "Seyyid" mahlâslı "Mehmed Sadık"ın 135. sayfadaki listede mahlâsı kısmının boş bırakıldığı, adı kısmında "Seyyid Mehmed Sadık" yazılı olduğu görülmektedir. 365. sayfada bu şairin ismi "...Seyyid Mehemmed Șādıḳ...", 371. sayfada "...Seyyid Meḥmed Șādıḳ...", 391. sayfadaki listede ise, "Seyyid" kısmı kaldırılarak ve sayfa 365 'te bulunduğu da yazılmaksızın "...Meḥmed Șāıḳ..." olmuştur. 135. sayfada "Sebzî, Sehmî, Va' dî, Vahîd" mahlâslı şairlerin isimleri "Muhammed", sayfa 385, 386 ve 388' de ise "Mehemmed"dir. "Avnî"nin ismi 135. sayfada "Muhammed" iken, 372. sayfada "Mehemmed", 391. sayfada ise "Meḥmed" okunmuştur. "Âsımî”nin 135. sayfada "Mustafa", 371. sayfada "Mehemmed" olan ismine, 391. sayfadaki indekste yer verilmemiştir. Bu bölüm vefeyatnamelerde yer alan şair isimlerinin birleștirildiği bir tablo ile sona ermektedir.

Sonuç ve Bibliyografya' yı vefeyatname metinlerinin çevriyazılarının verildiği Bursa Vefeyatnamelerindeki Şairlerin Biyografileri ve Sairler İndeksi izlemektedir. Kitabın sonuna Güldeste-i Riyâz-ı İrần (Gülbün-i Rabi'-Hamis)in Arap harfli metninin, hangi nüshaya ait olduğu ve varak numaraları belirtilmeksizin, fotokopisi eklenmiştir. $\mathrm{Bu}$ bölümde, beş vefeyatnamenin çevriyazılarından önce, kullanılan metoda ilişkin bazı açıklamalar da yapılmıştır. Bu yazının bundan sonraki kısımlarında önce, araștırmacının metinleri hazırlarken izlediği metot üzerinde durulacak; daha sonra çevriyazılarda görülen eksiklikler örnekleriyle birlikte maddeler hâlinde sıralanacak ve bazı beyitlerin okunuşları değerlendirilecektir. Bir değerlendirme yazısının boyutlarını aşacağı düşüncesiyle de, mensur kısımlar bir başka yazıda ele alınacaktır. 
Arap harfli metinlerin tümünü görmek mümkün olamadığı için herhangi bir öneride bulunulamayacak vezni bozuk beyitlerin ise, sadece sayfa numaraları işaret edilecektir.

1. "İkinci bölümde tablolar hâlinde gösterildiği için biyografiler kısmında yer alan şairlerin ayrıca listesi yapılmamıstır." (s. 159) ifadesi, 391. sayfadaki "Şairler İndeksi"ne kimi şairlerin dahil edilip, kimilerinin dahil edilmeme sebebini açıklamamaktadır.

2. "Metin tespit edilirken nüshası fazla olan eserlerde edisyon kritik yapılamamıș..." (s. 159) cümlesi şayet, "nüshası az olanlarda edisyon kritik yapıldı" anlamını taşıyorsa, çalışmanın bir bütün olduğu düşünülerek nüshası çok olan metinler de belirli ölçütler kullanılarak sınıflandırılmalı ve edisyon kritik yapılmalıydı. Ayrıca, “...yalnızca tereddüt doğan yerlerde karşılaştırılma yoluna gidilmiştir." gibi bir yaklaşımla metin hazırlamanın, nüsha farklarının kimi zaman verilip, kimi zaman verilmemesinden kaynaklanan bir karışıklığın doğmasına sebep olduğunu belirtelim.

3. Araştırmacı, XVII. yüzyıldan itibaren kaleme alınmaya başlanan vefeyatnamelerin -ele aldıkları şairlerin şiirleri dolayısıylaXIV. yüzyıla kadar uzandıklanını ve yazı çevrimlerinde imlâ birliği sağlamak amacıyla kelimelerin fasih şekillerninin göz önüne alındığını (s. 159) belirtmektedir. Kelimelerin fasih şekilleriyle, Arapça veya Farsçadan dilimize girmiş kelimelerin alındıkları dillerdeki telâffuzlarına uygunluk kastediliyorsa, bununla bağdaşmayan okuyuşlar olduğunu belirtmek gerekir: Meselâ, amān (s. 373)/ emān (s. 230), aşk (s. 332)/ 1şk (s. 206), bahā (s. 336)/ behā (s. 268), firḳat (s. 202)/ fürḳat (s. 340), gonca (s. 233)/ gonce (s. 309)/ gonçe (s. 302), menäre (s. 276)/ mināre (s. 257), mive (s. 202)/ meyve (s. 310) vb. kelimelerin fasih şekillerinin hangisi olduğu; Behzād (s. 266), çehre (s. 303), giysū (s. 323), hançer (s. 337), kūşe (s. 271), renk (s. 327), sühan (s. 287), tamām (s. 214), zamān (s. 241), zulumāt (s. 188) vb. kelimelerin fasih şekillerinin neye göre belirlendiği; bunların Bih- 
zād, çihre, gisū, hancer, gūşe, reng, suḩan, temām, zemān, z̧ulümāt/ zulemāt okunuşlanının niçin tercih edilmediği sorularının cevabını vermek mümkün değildir.

4. Metinlerdeki Türkçe eklerin okunuşunda, genellikle Eski Anadolu Türkçesinin dil özelliklerine uyulduğu anlaşılmakla birlikte, kimi yerlerde Eski Anadolu Türkçesindeki şekillerin tercih edilmediği görülmektedir. $\mathrm{Bu}$, aynı ekin farklı şekillerinin ortaya çıkması sonucunu doğurmuştur. Dil birliği sağlamanın güçlüklerinden söz eden araştırmacı, Türkçe eklerin yazı çevriminde hangi ilkeleri benimsediğine dair hiçbir açıklık getirmediği için, ikiliğin nedeni de anlaşılamamıştır (s. 159). Oysa, Türkçe eklerin çevrisinde nasıl bir tercih yapıldığından söz edilmeli ve bunun nedenleri üzerinde de durulmalıydı. Türkçe eklerin okunuşundaki farklılıkları metinlerden aldığımız bazı örneklerle somutlaştıralım: Meselâ, gördükce (s. 200), virmedükçe (s. 257), itdikce (s. 201), ḳılındıkcca (s.201); didügi (s. 258), giydigi (s. 224), gittigini (s. 268); yatduḳların (s. 243), oldıḳları (s. 246); süzülince (s. 378), dökülünce (s. 378); dilerüm (s.268), dilerim (s. 200), dökerem (s. 224); eksilmesün (s. 383), gitmesin (s. 383); aġzuma (s. 277), aġzıma (s. 350), makșūdıma (s. 228), girỉbānumı (s. 192), bağrımı (s. 333), bağrumı (s. 192); aduñ (s. 242), eyyāmuña (s. 386), rūyuñ (s. 385), āhiriñi (s. 242), yüziñi (s. 358), hüsniñi (s. 243); bulamaz (s. 256), bulımaz (s. 270); çaldum (s. 202), olmadım (s. 205); lālem (s. 327), teşneyem (s. 298), ḳudsem (s. 228), şütürüm (s. 228), șıfatum (s. 229), helāküm (s. 327); şerbetün (s. 246), dilin (s. 246)... Ayrıca, dāmāne (s. 192), pāyāne (s. 192), cāna (s. 192), mercāna (s. 192); kenāre (s. 331), dīvāra (s. 295), ag̉yāre (s. 205), yāra (s. 357), yāri (s. 340) ag̉yārı (s. 202); gayrıdan (s. 309), gayrden (s. 309 dipnot), örneklerinde de görüleceği üzere, Türkçe eklerde kalınlık-incelik uyumu açısından da kimi tutarsızlıklar görülmektedir.

5. Çalışmada, uzunluk işarctleri konusunda da birlik olmadığı dikkat çekmektedir. Birçok kelimede kısa ünlülere uzunluk işareti konurken, uzun ünlülerin bu işaret kullanılmadan yazıldığı 
görülmektedir: ālumı (s. 192), başlā (s. 373), belī (s. 358), beni (s. 205), fevtī (s. 214), hōos (s. 352), huldī (s. 352), Ḩuldiyāa (s. 352),

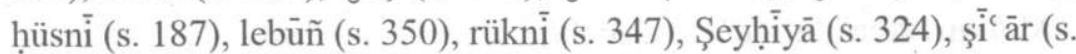
221), țākınca (s. 373), țūtdı (s. 358), yarlìg (s. 348); ah (s. 200), 'Arif (s. 200), Farisi (s. 331), kemha (s. 224), pars (s. 346)... Bu dikkatsizlik aynı kelimenin farklı yazımlarının da ortaya çıkmasına neden olmuştur: al (s. 288)/ āl (s. 297), ara (s. 213)/ ārā (s. 167), hoş (s. 221) / hōōs (s. 261)...

6. Metinlerde kimi zaman çizgi konmadan ve ayrı, kimi zaman çizgisiz ve birleşik yazılan kelimeler ve ön ekler dikkati çekmektedir: āf-tāb (s. 231)/ āftāb (s. 217), bī-hūde (s. 195)/ bīhude (s. 361), dem-ā-dem (s. 293)/ serāpā (s. 367), der-gāh (s. 356)/ dergāh (s. 348), dil-ber (s. 345)/ dilārā (s. 347), ebr-ile (s. 378)/ germile (s. 310), gonca-leb (s. 295)/ lāle ruhsār (s. 286), heft-ecrām (s. 189)/ nüh țāk (s. 348), her-kes (s. 293)/ her kes (s. 288), mū-miyān (s. 248)/ mūmiyān (s. 264), nā-tüvān (s. 264)/ nātüvān (s. 320), nev-reside (s. 328)/ nevres (s. 201), șad-çāk (s. 320)/ șad çāk (s. 192), sìm-ten (s. 187)/ sìm ten (s. 231), şiَrin-edā (s. 351)/ şūh țabī at (s. 350), kamercebin (s. 358)/ cādū nigeh (s. 337), şūrìde-ṣıfăt (s. 305)/ Ervāḥ șıfât (s. 300), ẓann-eyledüm (s. 350)/ haz̧ ider (s. 235) vb.

7. Özel isimlerin yazımında da tutarsızlıklar bulunmaktadır: Hażret-i Rabbi'l-Enām (s. 352), huālı̣̂-1 rabbi'l-enām (s. 214), Rabb-i Mecīd (s. 315), hażret-i hallāk (s. 347), șun '-1 Kadīi (s. 301), resūle'llāh (s. 320), Resūla'llāh (s. 207), Fahrr-i Kă` ināt (s. 232), fahrü'l-mürselin (s. 351), Ġılmān (s. 352), hūr-1 cinān (s. 292), ravża-i ' adn (s. 190), rāh-1 'Adn (s. 352), Mevlā (s. 272), mevlāyı (s. 324) vb.

8. Daha önce, metin içerisindeki kimi manzum kısımlarda vezin ve anlam bozuklukları görüldüğünden söz edilmişti. Aşağıda, sayfa numaraları takip edilerek, bunlardaki okuma yanlışlıkları düzeltilmeye çalışılacaktır. Düzeltilmesi mümkün olmayan vezni hatalı mısraların ise, sadece hangi sayfada bulunduğuna değinilecektir. Meselâ, 184. sayfada yer alan; 
Müft-i mesken șanur cihānı kişi

mısraındaki "Müft-i mesken" tamlaması "bedava mesken" anlamında "Müft mesken"dir. 186. sayfadaki;

Bāge-1 cūd-1 ebr keffinden țolu bārān-1 kerem misrainda vezin ve anlam hatalıdır. Misrain vezne, anlama ve Arap harfli metne (s. 396) göre doğru șekli şöyledir:

Bāg̀-1 cūd ebr-i kefüñden țolu bārān-1 kerem

187. sayfadaki;

Gūş-1 benefşeden șaḳın ey 'andelib-i mest

Gel ḥüsni rãzın açma kim yirüñ ḳulag̉ı var

beytinin ikinci mısraındaki "kim" bağlacı vezni bozmaktadır. Nitekim, eserin sonuna eklenen Arap harfli metinde de (s. 396) bu kelime "ki"dir. Misraın;

Gül hï̈sni rāzın açma ki yirüñ ḳulaġı var okunmasıyla da beyit anlamlı hâle gelecektir. 189. sayfadaki;

Gūy-1 çevgāna dönerdi kürre-i heft-ecrām mısraındaki "kürre" kelimesi hem vezni, hem de "sıpa, tay" karşılığı ile anlamı bozmaktadır. Kelime "küre" okunmalıdır. 192. sayfadaki;

İkisin țutsa idi ḳahr-1 ilāh

Mihr ü māh iderdi tahta külāh

beytinin ilk mısraında "İkisin" kelimesi tercih edilmiş ve nüsha farkı olarak "eksügin" verilmiştir. Oysa burada, "kusurunu yakalamak" anlamındaki "eksügin tutmak" deyimi tercih edilmeliydi. İkinci mısra ise, vezinsiz ve anlamsızdır. Beytin anlam ve vezince doğru şekli şöyle olmalıdır:

\section{Eksügin țutsa idi kahr-1 İlāh}

Mihr ü māh[1] iderdi tạ̣ta-külāh

Bu sayfadaki "ider" redifli gazelin üçüncü beytinin ikinci mısraında da vezin bozuktur. "Getürdüm" redifli gazelin ilk beytinin;

Āgāā-1 ser-kārumı pāyāne getürdüm

mısraının ise, vezin bakımından doğru şekli şöyledir:

Āgāa-ı ser-i kārumı pāyāna getürdüm

Bu gazelin ikinci beytinin birinci mısrainda da vezin bozuktur. Yine;

Hūūin müjelerden dil-i șad çāki gören dir

Dāmāna güli pençe-i mercāna getürdüm 
beytinin ilk mısraındaki "ṣad çāki" kelimeleri "ṣad-çāki" şeklinde yazılmalı ve ikinci mısraındaki "Dāmāna güli" ifadesi ise, anlam gereği, "Dāmān-ı güli" olmalıdır. 195. sayfadaki dördüncü beytin;

Kaldılar hayrān u dem-beste țabān-1 zamān misrainın vezne, anlama ve Arap harfli metne göre (s. 410) doğru okunuşu şöyledir: Ḳaldılar hạayrān u dem-beste țabībān-1 zamān 199. sayfadaki;

Erzān-1 metāc fażl u hüner tāo deñlü kim mısral, vezin ve anlam gereği;

Erzān metā' -1 fażl u hüner tã o deñlü kim okunmalıdır. Aynı kıt'anın;

Ebnā-yı dehr her hünerde āferīn virür

Yā Rab bu ne dükenmez hạinedür

beytinin her iki mısraında da vezin bozuktur. Nâbî'nin bu meşhur şiirinin ikinci beyti, malûm olduğu üzere, aşağıdaki şekildedir. Nitekim, Arap harf̣li metinde de (s. 409) yazım hatası bulunmamaktadır:

Ebnā-yı dehr her hünere āferīn virür

Yã Rab bu āferin ne dükenmez ḥazinedür 200. sayfadaki :

Gördükçe lebin ḥasretle ah idebilsem

Ol ġonca-i sūz-1 dile āgāh idebilsem

beytinin ilk mısra1 vezinsiz, ikincisi anlamsızdır. Beyit, Arap harfli metin de (s. 409-10) dikkate alınarak şöyle çevrilmelidir:

Gördükçe lebin ḥasretile āh idebilsem

Ol ġonçeyi sūz-ı dile āgāh idebilsem

Yine;

'Arif yine bezm-i sefer-i gurbet iderdüm mısra1 da Arap harfli metinde (s. 410);

'Ārif yine 'azm-i sefer-i gurbet iderdüm okunacak şekilde yazılmıştır ve anlamca düzgündür.

Dün görüp bir Yūsuf-1 hüsnüñ gam ile mest ü şevk

'Ārif-i şüridenüñ șordum nedür nedür endişsesi

beytini Arap harfli metne (s. 410) göre okursak, ilk mısradaki "gam ile"nin "gamıla" olması; ikinci misradaki "nedür nedür" 
kelimelerinden birinin çıkarılması gerekecektir. Böylece birinci mısradaki anlam ve ikinci mısradaki vezin bozukluğu ortadan kalkacaktır. Ayrıca ilk mısradaki "mest ü şevḳ"in diğer nüshalarda "mest-i şevḳ" biçimi varsa tercih edilmeli, yoksa metin düzeltilmelidir. Arap harfli metinde (s. 410) aynı şiirin ikinci beytindeki "bu tā"nın "tā bu", "sever"in "görür" yazıldığı, bu sayfada yer alan ikinci rubaînin üçüncü mısraındaki "aḥbābımuñ" kelimesinin ise, "aḥbābuñ" olduğu, fakat bunların hiçbirinin dipnotta verilmediği

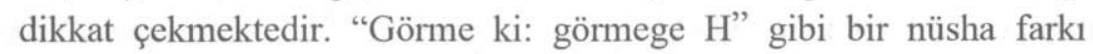
vermeyi -üstelik aynı kelimeyi iki farklı kelime gibi değerlendirip yanlış okuyarak- düşünen araştırmacının, asıl farklılıkları belirtmemesinin sebebi anlaşılamamıștır. 201. sayfadaki;

Dereke-i devlet-me ’ābuñda ḳılındıḳça namāz mısraının yazı çevrimi;

Dergeh-i devlet-me 'ābuñda kılındukç̧a namāz olmalıdır. Aynı sayfadaki tarih kıt'asının;

Kemāl-i 'ilmle meşhūr-1 āfāk

Ki ya'nī ol 'Așımi ol pīr-i nā-șād

beytinin doğru biçimi, Arap harfli metindeki (s. 409) yazım da dikkate alınarak, şöyledir:

Kemāl-i 'ilm ile meşhūr-1 āfāk

Ki ya'ni ' 'Āṣımi ol pīr-i nā-şād

202. sayfadaki kıt'anın ikinci mısraında ise, ekteki Arap harfli metne bağlı (s. 409) kalınarak "gird-āb-1 ġam u firḳate" okunan tamlama, 372. sayfada "gird-āb-1 gam-1 firḳate"dir ve anlamca da bu şekil uygundur. 204. sayfadaki beytin ikinci mısraında geçen "gögsüñ" kelimesindeki ek, Arap harfli metinde "ñ"la değil, doğru şekilde, "n" ile "كوكسون" (s. 408) yazılmıştır. 206. sayfadaki;

Nigāh-1 hasretle intizāāı baḳidür mısral, vezin gereği şöyle çevrilmelidir:

Nigāh-1 ḥasret ile intiẓāı bākịiür

207. sayfadaki naatın üçüncü beytinin ilk mısraındaki "başı" kelimesi, Arap harfli metinde (s. 397) "başın"dır. Yine;

Umar mahșserde senden Āzerīi bì-çāre sultānum 
mısraında vezin, "Āzerīi bi $\bar{i}$-çāre" tamlamasının, "Āzeri bī-çāre" okunması ile düzelecektir. 209. sayfadaki ikinci beytin;

Didi nev irtifā' rütbenüñ tārihhini Cevri

misra1;

Didi nev-irtifấc -1 rütbe[ñ] üñ tārihinini Cevrī

olursa vezin ve anlam bakımından düzgün hâle gelir. 211. sayfadaki

ikinci beytin;

Pāk ü bārid ü leżiz ü ' anber-bū

mısraı ise, vezin gereği şöyle çevrilmelidir:

Pāk ü bārid leziiz ü 'anber-bū

212. sayfadaki vezinsiz ve anlamsiz;

İdince bu haber-i sırdı o dem oldı

Meh-i felek ile hem-ser külāh kūşe āh

beytinin doğru biçiminin aşağıdaki gibi olabileceğini düşünmekteyiz:

İ[r]ince bu haber-i serdi [ki] o dem old 1

Meh-i felek ile hem-ser külāh-gūşe-i āh

214. sayfadaki;

Ehịbbādan birisi geldikde didi tārīh

mısraındaki vezni bozan "Eḥibbādan" kelimesi "Aḥbābdan" olmalıdır. 217. sayfada yer alan;

Bir gün ki harāret-i temmūzi

mısraındaki "temmüzi", vezin gereği "temūzi" okunmalıdır. 221. sayfadaki üçüncü beyitin ilk mısrar da vezinsizdir. Bu gazelin son beytindeki;

Bezm-i șafā-yı hōos tut şevḳ üzre müjde ḥaḳḳı mısraının yazı çevrimi şöyle yapılmalıdır:

Bezm-i șafãyı hoş tut şevḳ üzre müjde hạḳ̣ı

222. sayfadaki;

Olup kesb-i kemāl-i ma rifetde gün gibi meşhür

Kemāl ile ulūmuñ olmıșdı lübbine vāṣıl

beytindeki "kemāl-i ma'rifetde" tamlaması Arap harfli metinde "kemāl ü má rifetde"dir (s. 398). Tercih edilen şeklin hangi nüshadan alındığına ilişkin bir dipnot da verilmemiștir. İkinci mısrada ise vezin bozuktur. Mısra vezin gereği;

Kemāl ile 'ulūmuñ oḷmışidi lübbine vāṣıl 
okunmalıdır. Kıt'anın üçüncü beytinde, anlam gereği, "Kutup" kelimesi yerine Arap harfli metindeki (s. 398) "Ṭutup" tercih edilmelidir. Dördüncü beytin;

İşidüp intiḳālin Hāşimīi-i dā‘ $\bar{i}$ didi tārīh

mısraındaki "Hāşimī-i" vezni bozmaktadır. Kelime, vezin ve Arap harfli metinde hemzenin yazılmadığı göz önüne alınarak "Hāşimi " okunmalıdır. 224. sayfadaki;

Gümüş māhi șanursın sāḳ-1 simininini atladıḳca

Naẓar ḳılsañ derūn-1 ābda ol dürr-i nā-yābe

beytinin ilk mısraı vezinsizdir. Yazar, karşılaştırma yaparak, "atladıḳca"yı tercih etmiş ve "atdıḳca"yı dipnota atmıştır. Yazarın tercihi, vezni ve anlamı bozmaktadır. Oysa, "atdıkça" kelimesini kullanarak beyti, "(Sen), o bulunmaz (bir) inciye (benzeyen güzele) suyun içinde(yken) baksan, gümüş gibi (beyaz olan) baldırını attıkça gümüş balığı zannedersin." cümlesiyle anlamlı bir biçimde nesre çevirmek mümkün olacak, vezin de düzelecektir. Ayrıca, "Gümüş" kelimesi "Gümiş", "nā-yābe" de "nā-yāba" yazılmalıdır. "Sīmininini" kelimesindeki üçüncü “ī” ünlüsü ise, üçüncü teklik kişi iyelik eki olup uzun değildir. 230. sayfadaki ikinci beytin;

Cevr ile öldürür beni virmez emān ü zamān

mısraındaki vezinsizlik "ü" bağlacından kaynaklanmaktadır. 233. sayfadaki;

Gül rūyın o gonca fem bir kez mısral, vezin ve anlam gereği şöyle çevrilmelidir:

Gül-i rūyın o ġonca-fem bir kez

236. sayfadaki gazelin;

Şāhīn baḳışlu bir gözi mest-āne-i şeh-levend mısra1, vezin ve anlam gereği;

Şāhīn baḳışlu bir gözi mestāne şeh-levend okunmalıdır.

Düşdi ' așāya şiş̧e-i hecr içre derd ile

La' lüñden özge pāreleyüp özini ḳand 
beytinin ikinci mısraında vezni bozan "özini" kelimesinin yerine nüshalarda, "kendözini" gibi bir şekli olup olmadığına dikkat edilmelidir. Ayrıca, bu mısrada "özge" kelimesinin tercih edildiği ve "ayru" kelimesinin nüsha farkı olarak verildiği görülmektedir. Oysa, "ayru" kelimesi beyti anlamca doğru hâle getirecektir. Bu gazelin makta beytinin ilk misraında da vezin bozuktur. 238. sayfadaki tarihin son beytinin ilk mısraındaki vezinsizlik, Arap harfli metinde (s. 411) bulunmayan ve hangi nüshadan alındığı da belirtilmeyen "bir" kelimesinden kaynaklanmaktadır. 243. sayfadaki ilk beytin ilk mısraındaki vezin bozukluğuna ise, Arap harfli metinde (s. 418) "Neçün" yazılan kelimenin "Ni-y-çūn" şeklinde yanlış okunması neden olmuştur. Aynı sayfadaki altıncı beytin ikinci mısraında geçen “ancaḳ" kelimesi ise, Arap harfli metinde (s. 418) "el-ḥaḳ"tır. Yine;

Devr-i ruhında silsile-i zülfi dir gören

Cem` oldı gör teselsül ile devri cemele ?

beytindeki "cemele"nin yanına soru ișareti konmuștur. Kelime, anlam ve vezin gereği "cümleten” okunmalıdır. 244. sayfadaki kıt'anın son mısrandaki "zikrümi” kelimesinin, Arap harfli metinde (s. 401) "zikrüm" olduğunu da ekleyelim. 245. sayfadaki bendin;

Demidür baña 'adū itmek çū cevr ü sitem

mısraının doğru șekli, Arap harfli metindeki yazım (s. 401) ve vezin de dikkate alınarak, şöyledir:

Dem midür baña 'adū itmekiçün cevr ü sitem

247. sayfadaki ilk beytin ilk mısraı "gelsün"lc bitmektedir. Oysa Arap harfli metinde (s. 401) misra sonundaki kelime "merde"dir. Hem gazelin kafiyesi, hem de anlam bakımından "merde" uygundur. Dördüncü beytin;

Ezelden kendi zātuñ cenge mü tād eyleyen gelsün mısraındaki "zătuñ" Arap harfli metinde (s. 401), anlamca da doğru șekilde, "žātın" yazılıdır. Beşinci beytin;

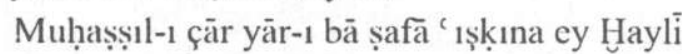

mısraının yazı çevrimi, anlam ve vezin dikkate alınarak, şöyle yapılmalıdır:

Muḷạṣ̣al çār-yār-ı bā-șafá 'ıșḳına ey Huayli 
Aynı sayfadaki "Ebyāt" başığıyla verilmiş beyitlerden ikincisinin ilk mısraında "hatṭ-1 müşg-bārsuz" tamlamasının "ḩaț-1 müşg-bārsuz" okunmasıyla vezin düzelecektir. Yine;

Degüldür șāḷ̣-1 gülde görinen huār ey boyı ' ar' ar

Düșüp ter bülbül-i șcydāya gül-bün oldı dal-ḩançer beytinin ikinci mısraı anlamsızdır. Arap harfli metinde (s. 402) "تر" "yazılı kclimenin "degüldür”"e paralel “düşüptür” okunmasıyla mısra "Gülbün, yalın hançer oldu şeyda bülbüle hücum etmiștir." şeklinde nesre çevrilebilecektir. Bu çcviride anlam tümüyle bozuk olmamakla birlikte, "oldı" kelimesindeki ekten dolayı cümlenin aksadığı görülmektedir. Nitekim "oldı"nın, Arap harfli metinde (s. 402), "öri” yazıldığını da eklemek gerekir. Mısra;

Düșüptür bülbül-i şeydāya gül-bün öri dal-ḩançer okunduğunda anlam kazanacak ve nesre çevirisi de, "Gülbün, dik (ve) yalın hançer (biçimde) șeyda bülbüle hücum etmiştir." şekline dönüşecektir. Sayfadaki son beyitte yer alan "ol" sıfatı ise Arap harfli metinde "o"dur (s. 402). 251. sayfadaki ilk beytin ikinci mısranda da vezin bozuktur. 255. sayfadaki;

Da' vā-i fażl-ı peder itme maḩādīm-i dem iseñ

Şeref-i nesl ile fahrr itme ger ādem iseñ

beytinin ilk mısra, anlam ve vezin gereği;

Da'vī-i fażl-1 peder itme mahāedīm-dem iseñ

yazılmalı ve ikinci mısradaki "ger"in, nüshalarda mevcutsa, vezin bakımından daha uygun olan "eger" șekli tercih edilmelidir. 256. sayfadaki;

Bulamaz İstānbūla beñzer bir șehr

mısraının vezne uygun çevirisi șöyledir:

Bulmaz İstanbula benzer bir șehr

259. sayfadaki "sevmez" redifli manzumenin;

Dilde yaḳdı maḥabbet-i nārm

mısraunda. "mahabbet-i" kelimesi, anlam gereği. "maḥabbet[i]" okummalıdır. 261. sayfadaki "bilmez" redifli gazelin dördüncü beytinin ilk mısrı da vezinsizdir. Ayn gaıelin: 
'Urūc-1 cvci kor rāsti nevā nedür bilmez

mısraındaki " ḳor" kelimesi, vezin ve anlam gereği, "bırak" anlamında "ḳo"olmalıdır. Ayrıca, "nev" redifli gazelin üçüncü beytinin;

Yüz țutdı gunca gonca ile yine tebessüme mısraındaki vezin ve anlam bozukluğu;

Yüz țutdı gonca gancıla yine tebessüme seklinde okunursa düzelir. 262. sayfadaki ikinci beytin;

Ol șāh-ı hüusn ü Husrev ü milk-i melāhate mısraı, anlam gereği așağıdaki șekilde çevrilmelidir:

Ol şāh-1 ḷ̣ïsn ü ḥusrev-[i] milk-i melāhate 263. ve 379. sayfalardaki;

Hāme-i țab ${ }^{`}-1$ Belìg itdi raḳam-1 tārỉhin mısranda da vezin ve dolayısıyla anlam bozuktur. Oysa, "raḳam-ı tārihhin" tamlaması yerine "raḳam tārihhin" okunursa, yüklem "rakạm itdi"' olacak, böylece vezin ve anlam düzelecektir. 264. sayfadaki:

Şürü itmiş gibi buațtẹ rủḥı dil-dārı taḥrire

Lisān-ı kilk-i Kātibden çıḳan hep güfte-gū tãze

beytinin ilk mısraındaki "rūḥı dil-dārı", arkadaki metne (s. 412) bağlı kalınarak okunursa, "ruhy-ı dil-dārı" olur. İkinci mısradaki "güftegü"nun doğrusu ise, "güft-gū"dur.

Ter ü tāze olur lyāme 'acebdür dest-i Kătibden

Yazarken medḥ-i vãlă-yı ḳaddin ol serv-i bālānuñ

beytindeki "Kātibden" kelimesi, Arap harfli metinde (s. 412) "Kãtibde"dir ve anlamsızlık da olușturmamaktadır. "Kätibden" șeklinin hangi nüshaya ait olduğuna dair bir dipnot da verilmemiștir. İkinci mısada ise "ḳadin" okunması gereken kelime "ḳaddin" okunduğu için vezin bozuktur. Dokuzuncu beytin;

Kilk-i medîhạa-güyı dū șaḳ oldı Kãtibüñ

misral;

Kilk-i medị̣ạı-gūyı dü șıḳk oldı Kätibüin

okunmalıdır. Gerek anlam, gerek Arap harfli metindeki yazım (s. 412) da doğru șeklin "yarma, yarılma; yarık, çatlak" anlamlarındaki "șaḳk" olmadığını, "ikiye bölünmüss șeyin her parçası anlammındaki" "sııḳ" olduğunu göstermektedir. 268. sayfadaki; 
Dem-be-dem cīn u gönìil iñlese ney gibi revā

Kim ki sinn-i serve gönül vire olur chl-i hevā beytinin ikinci mısar;

Kim ki sen serve gönül vire olur chl-i hevã okunursa düzclir ve beyit, "Can ve gönül, ney gibi daima inlese reva(dır); (çünkü) sen servi (boyluya) gönül veren kimse ehl-i heva olur." șcklinde nesre çevrilebilir. Bu gazelin;

Hūn-bchā-yı dudagìndan dilcrüm didi gözüñ mısraındaki "Hūun-bchā-yı"nın doğru yazımı "Hūn-bchāyı"dır. Yine, maktan;

Lāmi ‘ $\bar{i}$ anuñ-çūn cān u dili eyledi terk mısraı, vezin gereği şöyle olmalıdır:

Lāmi ‘ $\bar{i}$ anuñ $[i]$ çün cān u dili eyledi terk 269. sayfadaki ikinci beytin ilk mısraı da vezinsizdir. 276. sayfada yer alan;

\section{Dönüp menäre nihāl-i güle}

mısraında vezin bozuktur. Nüshalarda, "Dönüp" kelimesinin "Dönüp[dür]" gibi vezni tamamlayan ve anlamı da bozmayan bir yazılışının bulunup bulunmadığı kontrol edilmelidir. 277. sayfadaki ikinci beytin ilk mısra da vezinsizdir. 279. sayfada bulunan;

Topl çarh-ı dehr elinde oynadur elma gibi mısraı anlam gereği;

Top-1 çarh[ [1] dehr elinde oynadur elma gibi

okunmalı ve "Ṭopl" kelimesine "IḲop: Kol? H" şeklinde verilen hatalı dipnot da düzeltilmelidir. 283. sayfadaki altıncı beytin ilk mısra da vezinsizdir. Yedinci beytin;

Yã mu' teḳif-i kụdsem yā deyr-i Frengem mısraının vezinsizliği, Arap harfli metinde "kudsem" kelimesinden sonra gelen (s. 414) "ü" bağlacımın yazılmamasından kaynaklanmaktadır. 287. ve 382. sayfalardaki nazmın vezinsiz;

Aṣ̂l māla ki odur uṣūl-i ḳadīm

mısraı aşağıdaki şekilde çevrilmeliydi:

Aṣl-1 māla k'odur uṣūl-i ḳadīm 
Sayfa 288 ve 383 'teki "gül-zārı cihānda", anlam ve Arap harfli metindeki (s. 415) imlâ gereği, "gülzār-ı cihānda" yazılmalıdır. Yine 288. sayfadaki;

Ġonca-i ețfâli gibi ' 1yd-geh-i gül-şende

Bülbüle șāh-1 gül alı semend itdi șabā

beytinin her iki mısraı da vezinsiz ve anlamsızdır. Beyit, Arap harfli metin de (s. 415) dikkate alınarak, şöyle okunmalıdır:

Ġonçe ețfâli gibi ' yydgeh-i gülșende

Bülbüle șāhn-1 gül-i alı semend itdi șabā

Yine;

Gülmedüm 'ālemde aṣlā olmadum mesrūr-1 hạāl

Hem demüm derd ü elemümdür maḥremüm her dem melāl matlaının ilk mısraında anlam, ikinci mısraında vezin hatalıdır. Beyit;

Gülmedüm 'ālemde aṣlā olmadum mesrür-ḷaāl

Hem-demüm derd ü elemdür maḥremüm her dem melāl yazılmalıdır. Nitekim Arap harfli metinde de (s. 415) "elemümdür" kelimesinin "clemdür" olduğı açıkça görülmektedir. Ayrıca;

Dereke-i dāre varırsam ḥalime a' dā güler

mısranın yazı çevrimi -Arap harfli metnin imlâsı, araştırıcının benimsediği dil özellikleri, vezin ve anlam göz önüne alınarakaşağıdaki şekilde yapılmalıdır:

Dergch-i dāra varursam hālüme a' dā güler

289. sayfadaki ilk beyitteki "Bursaya" kelimesinin "Burūsaya", ikinci beyitteki "Ṭa mda" kelimesinin "Ṭa āmda" ve dördüncü beyitteki "medḥinüñ" kelimesinin "medhüiñ" okunması mısraların veznini bozmuştur. Arap harfli metinde de (s. 414) kelimelerin yazımı, çevriyazıların işaret ettiğimiz șekillerde yapılmasına uygundur. 290. sayfadaki;

Taḷ̣kịk ise ger nükte-i el-leyletü'l-ḥublā

mısrandaki vezinsizlik, Arap harfli metinde "الليلة حبلى (s. 413) yazılan sözün yanlış okunmasından kaynaklanımıștır. Mısra, aşağıdaki sckilde yazılırsa vezin düzelecektir:

Tahḷkik ișe ger nükte-i cl-leyletï ḷublā

293. sayfadaki ikinci beyitte geçen kelime "Gești" değil "Kești" dir. 295. sayfadaki; 
İtdi o mehünn kevkebe-i pertev-i hüsni

Endāh̆te-i bām-ı felege kebşs-i hilāli

heytinin ikinci mısranda tamlama yanlıșı bulunmaktadır. Metindeki "انداخت: باد" (s. 4()2) yazımı tamlama olduğunu ișaret eder gibi görünmekteyse de "İndāhte" kelimesindeki med hece düşünülünce hemzenin kaldırılmasının vezni bozmadığı, aksine tamlamanın anlamsızlığa yol açtığı ortaya çıkmaktadır. Dolayısıyla, mısra;

lindāhlyte bām-1 felege kebși-i hilāli

okunmalıdır. 297. sayfadaki ilk beytin;

Sükker-istāndur bu meelis āl-i țutțieür şarāb

mısranndaki "āl-i țịtịdür" tamlaması "al țūtidürr" olmalıdır. Sayfanın sonundaki mısrada ise yazar, "ḳabre" kelimesini "ḳabr[c]" şeklinde yazmıs ve dolayısıyla metin tamiri yaptığını ișaret etmiștir. Oysa bu kelime, Arap harfli metinde de (s. 403) "kabre" okunacak şekilde yazılmıştır. Bu nedenle "e"yi ayraç içine almaya gerek yoktur. 298. salyfadaki ikinci beyitte yer alan "rūḷ" kelimesi Arap harfli metinde "süby"tur. Dördüncü ve sekizinci beytin ilk mısraları isc, Arap harfli metinde (s. 403) bulunmamaktadır. Fakat, bunlara ilişkin herhangi bir dipnot verilmemiștir. Yine;

Şehādet-i àrzì ol teșneyem kim çeşm-i ümìdem

Mișail-i meve-i cevher hạalḳa salḳa ḳaldı ḥançerde beytinin anlamı ve birinci mısaunda vezni bozuktur. Arap harfli metne (s. 403). anlatma ve vě̉ne uygun çeviri șöyledir:

Schñhet-ārzù ol teșneyem kim çeșm-i ümmidüm

Mișill-i meve-i cevher halḳ̣a halḳa ḳaldı haneerde

Aym sayfadaki:

Şadii-yı ra' d pür züri münebbihden 'ibäretdür

Nigāh olsa felek bir iki günki ḳubbe-i sā̃ atdur ic ֻุinin. Arap harfli metin (s. 403) göz önüne alınarak;

Sildi-yı ra' d-1 pür-zürı müncbbihden 'ibäretdür

Nigith olsa felek bir iki günki ḳubbe sā' atdur

scklinde çevrilmesi anlamun ve veznin düzelmesini sağlayacaktur. Sily fi 294 daki beytin ilk mısaunda geçen "meczüubiyyän" kelimesi weın gereği "meczubiyän" ve sayfa $3000^{\circ}$ deki gazelin ikinci

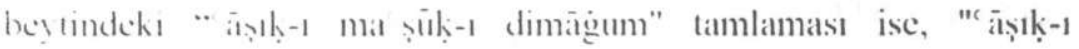


ma'șūk-dimāgam" yazılmalıdır. 301. sayfadaki dördüncü ve beşinci beytin ilk mısralarındaki "şükr" ve "bुışm" kelimeleri, vezin gereği, Türkçe söyleyişe uygun biçimde "şükür" ve "hışım" okunmalıdır. Gazelin maktaındaki "mư ciz kelimātum" ifadesi, anlamın doğru verilebilmesi için, "mu’ciz-kelimātam"; "mírüm", "vezirüm",

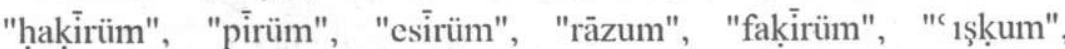
"ḥaḳirüm", "Kadirüm" kelimeleri ise, bildirme ekiyle "mírem", "vezirem", "hakịirem", "pirem", "esīrem", "rāzam", "faḳirem", "‘ ıșkam", "ḥaḳirem", "Kadirem" okunmalıdır. Sayfa 302'deki;

()) rind-i 'ārifüz ki bizüm du' āmuzı

Kevn ü mekāna alsa kiși rāygāndur

beytinin ilk mısrandaki vezin bozukluğu kelime eksikliğinden kaynaklanmaktadır. "Bizüm du'āmuzı" ifadesinin, "bizüm [bir] du'āmuzı" gibi anlamı da tamamlayabilecek bir şekli bulunmalıdır. 303. sayfadaki;

Hyitān oldı üstād-1 șabā bi'llāh bu tārīhnde

Gūyiyā bir gonçe-i zanbaḳdan itdi ' ‘ḳdı țarḥ

beytinin ilk mısranda vezin ve anlam, ikinci mısranda ise anlam bozuktur. İlk mısra1, Arap harfli metinleri görmeden düzeltmek mümkün değildir. İkinci mısra ise, "' 1 dè" kelimesinin "'akdı" okunmasıyla anlamlı hâle gelecektir. 305. sayfadaki son beytin;

İtdi tekliff-i nażirüñ bizi șā' ir Resmi

mısrandaki "naziirüñ" kelimesi anlam gereği "naz̦íreñ" olmalıdır. Aynı beytin ikinci mısraındaki "ez-in" kelimesine verilen nüsha farkı "zeyn" de yanlıștır. "Zeyn" yerine "ez-inn"in kısaltılmıș șekli "zín" yazılmalıdır. 306. sayfanın sonundaki beytin ilk mısra vezinsizdir. 308. sayfadaki ilk beytin ilk mısranda ise, Arap harfli metindeki (s. 403-404) "yine" kelimesinin atlanması vezni bozmuştur. Mısraın doğru șckli şöyledir:

Aldı ḳalem eline yine eski ‘ādetin

İkinci beytin;

Germābe-i Bursayı medh itmek istedi

mısranda "Bursayı" kelimesini, "Burusayı" okumak vezin bozukluğunu düzcltecektir. Sayfanın sonundaki gazelin kimi mısralarında da hatalar nevecuttur. İkinci bcytin; 
Āsumān hergīz degül yanında hem-ḳaddür hạabāb mısra, anlamın doğru verilebilmesi için;

Āsumān hergiż degül yanında hem-ḳadr-i habāàb olmalıdır. Son beytin vezinsiz;

Sem' -i bezm-i aş̣ạa per yaḳmıș Sebzi gibi

mısraı, Arap harfli metinde (s. 404) așağıdaki gibidir:

Şcm -i bezm-i ‘ ıșḳa per yaḳmış dil-i Scbzi gibi

309. sayfadaki;

Bir gül açıldı ḳatı çoḳ rūzgārdur

mısraındaki vezin bozukluğu, Arap harfli metinde (s. 404) "açılmadı" yazılı kclimenin "açıldı" okunmasından kaynaklanmaktadır. Ayrıca;

'Āṣık olan o șūha meger Nūḥ 'ömri ola

mısra, Arap harfli metinle (s. 404) uyussmamaktadır ve bu farklılık dipnotta belirtilmemiștir. Mısra, Arap harfli metne uygun okunursa vezin de düzelir:

Yine;

'Āşık olan o şūha meger ‘ ömr-i Nūḥ ola

Ķıyās itdüm ki anı şimdi gelür cehennemden

mısranın yazı çevrimi ektcki metne (s. 404) uyarak yapılsaydı, vezinde herhangi bir hata olmadığı görülecekti:

Ḳıyās itdüm ki anı şimdi gelmişdür cehennemden

310. sayfada yer alan ikinci beyitteki "bahtuñ" kelimesi Arap harfli metinde (s. 404) "tahtuñ̄"dur. "Ebyāt" başlığı altındaki beyitlerden ilkinin;

Tünd-bād-1 nālem eylerdi sipihr-i ser-nigūn mısrandaki "sipihr-i ser-nigūn" tamlaması Arap harfli metinde (404) "sipihri ser-nigūn"dur ve anlamca da bu doğrudur. Sayfanın sonunda ve aynı zamanda 387. sayfadaki kıt'anın ilk mısraındaki "Şive-i fenninde" tamlaması vezni ve anlamı bozmaktadır. Oysa tamlama, Arap harfli metinde (s. 404) "Şive fenninde" okunacak şekilde doğru yazılmıștır. 311. sayfadaki birinci beytin vezni hatalı ilk mısraındaki "la lüyle" kelimesi, Arap harfli metinde (s. 404) "la' lünnile"dir ve vezin de düzgündür. 313. salyfada bulunan ikinci ve dördüncü beyitteki "ümid" kelimesi, vezin de göz önüne alınarak, "ümmid" okunmalıydı. 317. sayfadaki tarihin ikinci beytinin; 
Ḳoyup bu vaḷ̣set-ābād dünyā-yı dūnı mısraındaki "bu" kelimesi vezni bozmaktadır. 320. sayfadaki gazelin;

Ne hōoşdur eylese neẓz̄āre-i luțfuñla mahșserde

Ruḩ-1 cirmi hịicāb-1 'afv-1 kül gül yā resūle'llāh beytindeki anlamsızlık, ikinci mısraın aşağıdaki şekilde okunmasıyla giderilir:

Ruh-1 cürmi hicāb-1 ' afv gül gül yā Resūla'llāh

İlk mısradaki "hōşşur" kelimesinde uzunluk işareti olmadığını da ckleyelim. Son beyitteki "ruhlarınuñ" kelimesi ise, Arap harfli metinde (s. 405) "ruhllaruñuñ"dur. 322. sayfadaki;

Āyāne güneh eylemişüz hāk-i rehüñde

mısrandaki "Āyāne" "acaba ne" anlamında iki ayrı kelimedir. Bu nedenle "Āyā ne" şeklinde yazılmalıdır. Ayrıca;

Ümmíd-i șubḥ eylemesün şãm-1 gamuñda

mısraında "ṣuḅ̣" kelimesi vezni bozmaktadır. Bu kelime muhtemelen "ṣabāḥ"tır. 323. sayfadaki vezinsiz ve anlamsız;

Dirdüm ki beyāża çaḳa giysū-yı sevādı

Müşkil bu dahı̆ ḳaraldı ḩațt-1 mecīd

beytinin diğer nüshalarda, aşağıdaki gibi vezinli ve anlamlı bir şekli bulunabilir:

Dirdüm ki beyāża çıḳa gisūi-yı sevādı

Müsskil bu daḩı ḳaraladı ḩațt-1 Mecid[i]

324. sayfadaki yedinci beyitteki "cömr" kelimesi vezin gereği “" ömür"dür. 325. ve 388. sayfadaki;

Elüñ degse șunarduñ ḳurș-1 māha ey ḥasūdü'l-ḥak mısraı, anlama dikkat edilerek, şöyle çevrilmeliydi:

Elüñ degse șunarduñ ḳurṣ-1 māha ey ḥasūd el-ḥak 327. sayfanın sonundaki "ebyāt" başlıklı bcyitlerin ilkinin ikinci mısra da vezinsizdir. İkinci beytin ikinci mısrandaki vezin bozukluğu ise, "içcrdi"nin "içcridi" okunmasıyla düzelir. 328. sayfadaki ilk beytin;

Dirìg u der kiḩ geçmekde rūzgār-1 șcbāb

mısraına anlam vermek mümkün değildir. Ayrıca vezin de bozuktur. Mısraın, Arap harfli metne (s. 407) de dikkat edilerek, çevriyazısı aşağıdaki şckilde yapılmalıdır: 
Dirìg u derd ki geçmekde rūzgār-1 șebāb

Üçüncü beytin vezinsiz;

Dendān nișānesi lebüñ̀de nedür didüm

mısramın, nüshalarda așağıdaki gibi vezni düzgün bir şekli bulunacaktır:

Dendān nişānesi [mi] lebüñ̀de nedür didüm

Dördüncü beytin;

Bulur būy-i buhūir-ı Meryem makșūūı kāmında

mısraında geçen "buhūur-1 Meryem makșüù" ifadesinin "bahụur-1 Meryem-i makșūdı" okunması vezni de anlamı da düzeltir. Yine;

'Uşşāḳ-1 telh-kāme ag̉ız miski 'arż ider

Şekker-fürūș olup hatț-1 leb-i nev-demideler

beytinin ikinci mısraını;

Şekker-fürūş olup hatẹt-ı leb-nev-demideler

okumak vezin bozukluğunu düzeltecek ve beyit, "Dudakta yeni bitmiş tüyler, şeker satıcı olup kederli (damağı acı) âşıklara ağız miski arz eder." șeklinde nesre çevirebilecektir. 329. sayfadaki;

Böyle bir fãżıll-1 hünerüñ Hak dilerüz

İde ārāyiş destī ḳalem-i āf-tābı

beyti, hem vezin hem de anlamca bozuktur. Arap harfli metni (s. 407) dikkate alarak atlanmış kelimeyi ilâve eder, gerekli yerde tamlama yapar, uzun olan eki kısaltır ve yanlış okunan kelimeyi düzeltirsek heyit șu șckli alır:

Böyle bir fäżıl-ı șăḥib-hünerüñ ḷ̣aḳ dilerüz

İde ārāyiș-i desti ḳalem-i iftāyı

332. sayfadaki "eyleyen" redifli gazelin ikinci beytinin ilk mısraındaki "Vașluñdur" kelimesinin "Vuṣlatuñdur" olması vezni düzcltecektir. 335. ve 388. sayfalardaki;

Salma gird-āb-ı gama felck dili luṭf eyle mısraının vezne ve anlama uygun şekli şöyledir:

Şalma gird-āb-ı gama fülk-i dili luṭf eyle 336. sayfadaki:

El-Hak ne dil-rübã șanem dil-pezir olur mısraı, vezin ve anlaum gereği;

l:I-ḷak ne dil-rübā șanem-i dil-pežir olur 
okunmalıdır. 337. sayfada yer alan ve ilk mısranda vezni de bozuk olan;

Ralıne eylese ol șūh perīşān zülfin

Her şikencinde nice mihr-i dırahșān görinür

beytinin bu okunuşa göre nesre çevirisi ancak, "O şuh, dağınık zülfünü yarık cylese her kıvrımında nice parlak güneş görünür." şeklinde yapılabilir. Beyitteki anlamsızlık, yanlış okumadan kaynaklanmaktadır. İlk mısra;

Ruhına eylese ol șūh perișān zülfin

okunursa, hem mısraın vezni düzelir, hem de beytin nesre çevirisi anlamca doğru hâle gelir: "O șuh, zülfünü yanağına dağıtsa, her kıvrımından nice parlak güneş görünür". Dördüncü beyitteki "i ‘ cãza ḳarinn" kelimeleri Arap harfli metinde (s. 417) "i`cāz-ḳarīn"; "bu" kelimesi ise, "nev" okunacak şekilde yazılmıștır. Eğer farklı şekiller, diğer nüshalardan kaynaklanıyorsa, bunların dipnotta gösterilmediğini de eklemek gerekir. Aynı sayfadaki "ebyāt" başlığı altında verilen ilk beyitte geçen "Kaābe ḳavseyn-i ev ednā..." âyeti "Kạabe ḳavseyni ev ednā..." yazılmalıdır. Ayrıca;

Çeker terāşemi ḳymetde la' lle hem-ser iden

Ümìd ile ü leb-i cān-fezā-yı dil-berdür

beytinin ikinci mısraının, Arap harfli metne (s. 417) göre çevriyazısı şöyle olmalıdır:

\section{Ümīd-i la' l-i leb-i cān-fezā-yı dil-berdür}

Yine de beyitte ilk misradan kaynaklanan bir anlamsızlık mevcuttur. Düz yazıya, "En küçük parçamı kıymette lâl taşı ile denk eden çcker; dilberin can artıran dudağının ümididir." șeklinde yapılabilecek çeviride bu durum daha da belirginleșmektedir. Anlamsızlık ilk mısradaki "جَ" (çeker) kelimesinden kaynaklanmaktadır. Sözlüklerde bu yazılıșta ve beytin anlam bütünlüğünü sağlayacak bir kelime bulamadık. Bu kelime, "la' l" ile ilișkisi de düşünülürse, "ciger" 
olmalıdır. Böylece beytin anlamea doğru çevirisi, "Ciğerimin en küçük parçasını kıymette lâl taşı ile denk eden, dilberin can artıran dudağının lâlinin ümididir." şeklinde yapılabilecektir. Ayrıca, nüshalarda ilk mısradaki "la' lle" kelimesinin, vezin bakımından daha doğru olan ve anlamı da bozmayan "la' l[c]" șekli varsa tercih edilmelidir. Bu sayfadaki sekizinci, 389. sayfadaki birinci beytin;

Habb-i miskindür ki terkỉb-i gül-äb-1 ālūdedür mısra, Arap harfli metinle (s. 417) uyumsuz, vezin bakımından da hatalıdır. Misra;

Ḥabb-1 miskīndür ki terkỉbi gülāb-âlūidedür şeklinde çevrilmelidir. Yine, araştırmacımın;

Duhter-i rez hiç degül hem-şire-i ț̣fl-ı dilc

Kim gelür bōstān-1 sāgàar șîr-i māderden ležizz

okuduğu beyit ise, "Üzümün kızı (șarap), gönül çocuğunun süt kardeşine hiç değil (olamaz); çünkü (ona), kadehin bahçesi anne sütünden leziz gelir." cümlesiyle ve anlamsız bir biçimde nesre çevrilebilir. Beyit;

Duhter-i rez hịç degül hem-şirei ț̣fl-ı dile

Kim gelür pistān-1 sāgar şir-i māderden ležiz

okunursa, nesre çeviri de "Üzümün kızı (şarap), gönül çocuğuna bir süt kardeş hiç değil (olamaz), çünkü (ona), kadehin memesi anne sütẗ̈nden leziz gelir." şekline dönüsserck anlam kazanır. Onuncu (sayfa 389'da ikinci) beytin;

Yine āşüfteler hāạtır-1 perişān olmasun dirsüñ

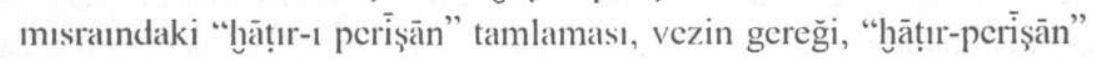
okunmalıydı. Sayfa 340'taki;

Vaṣl u firäk yāri benden su’āl cylen

mısraının anlamca doğru şckli;

Vaṣl u firākẹ-ı yāri benden su āl eyleñ

olmalıydı. Sayfa 346 'da yer alan;

Ḩațt-1 berde olan tāzelerüñ çihresi şimdi

Mi` mār Dedenüñ kııṭ alı dükkānına beñzer

beytindeki ilk mısran hem anlamı, hem de vezni bozuktur. Mısran yazı çevrimini:

Haț-bürde olan tāzelerüñ çihresi șimdi 
biçimine dönüştürerek, beytin nesre çevirisini anlamlı bir biçimde yapmak mümkündür: "Şimdi, sakalı çıkmış gençlerin çehresi Mimar Dede'nin kıt'alı (duvarına kıt'alar yazılmış) dükkânına benzer." 347. sayfadaki dördüncü beytin vezni bozuk;

Șafḥa-i dīvārı hem-çūn āyine-i berrāḳdur mısraı şöyle okunmalıdır:

Șafhạa-i dīvārı hem-çün āyine berrāḳdur

Yine, anlamı ve ikinci mısrada vezni de hatalı;

Dāg̉dur gül-mīhnı gūyā sine-i münkerlere

Ṭarz-1 yede ' 1 dedu'l-lisān-ı zāhid-i zerrāḳdur

beytinin yazı çcvrimi aşağıdaki şekilde yapılmalıdır:

Dāğdur gül-mîhı̉ı gūyā sine-i münkirlere

Ṭarzı da 'aḳdu'l-lisān-1 zāhid-i zerrāḳdur

Sayfanın sonundaki iki beyitten ilkinin ikinci mısraındaki vezin hatası ise "görinür" kelimesinin "göriniyor" okunması kaynaklanmaktadır. 348. sayfadaki;

Zihì kitāb-1 bedíc ı'l-beyān-1 belīìı'l-edeb

mısranda vezin bozuktur. Misra;

Zihì kitāb-1 bedī' ü'l-beyān belig̈ü'l-edeb okunmalıdır. Ayrıca;

Çū yazdı emr-i belāgatda münşiyān-1 menşūr mısranın yazı çevrimi vezin ve anlam gereği şöyle olmalıydı:

Çü yazdı emr-i belāgảatda münșiyān menşūr

349. sayfada yer alan gazelin ikinci beytinin ikinci misrainda da vezin hatalıdır. 350. sayfadaki son beytin ikinci mısrandaki "Burūsada", vezin gereği "Bursada" yazılmalıydı. 352. sayfada yer alan tarihin;

Huldi șāḥib-i kemāl ü ma'rifet

Şā' ir-i pākize tạ ${ }^{c}-1$ hōos kelām

beytinin doğru yazı çevrimi şöyledir:

Huldī -i șāḥib-kemāl ü ma rifet

Şà' ir-i pākīze-țab` [ü] hoș-kelām

Yedinci beytin;

Rāh-1 'Adni eyledi bir iki kām

mısraındaki son kelime, "adım" anlamında "gām"dır. 353. sayfadaki; 
Nuzzāara kühen-i ni' met-i luțfiyla pür itmiș mısraının hem vezin, hem de anlamea doğru șekli șöyledir:

Nezzāregehin ni' met-i luṭfiyla pür itmiş

Yine, bir murabbadan alınan bendin;

Göñlüm yine bir serv-i kade yār olayum dir mısraındaki "serv-i ḳade" tamlaması "serv-ḳade" olmalı, aynı bendin;

Āşüfte-i ser țurra-i țarrār olayum dir yazılan son mısraı isc, așağıdaki gibi çcvrilmelidir:

Āşüftc-ser-i țurra-i țarrār olayum dir

Bu bend, sayfa 377 'de de yer almaktadır. Üçüncü mısrannda "yine" kelimesi yazılmamış; son mısraın okunuşunda da aynı yanlışlık tekrarlanmıstır. 354. sayfadaki;

Gördüm ki dārh münāsebcti hüisn-i yār ile

Āhar 'alāḳa eyledüm evvel bahār ile

beytindeki anlamını tespit edemediğimiz "dārḩ" kelimesi muhtemelen "var"dır. "Evvel-âhir" münasebeti göz önüne alınırsa, "Āharar" kelimesini "Āhir" okumanın daha doğru olacağı da düşünülcbilir. 355. sayfadaki;

Teselli-bahş̧ olur erbāb-1 '1ş̣ạ künc-i mihnetde

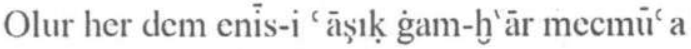

beytinin ikinci mısranda vezin bozuktur. Mısra șu şckilde çevrilmelidir:

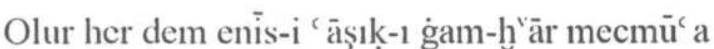

Bu mısradaki "Olur"un nüshalarda "Olan" şckli varsa tercih edilmelidir. Yine, vezni bozuk:

'Amā kim mevrid-i envā'-1 ni' amā-yı ilāhìdür mısraını, vezin gereği;

'Amā kim mevrid-i envā' -1 na' mā-yı ilāhīdür yazmak gerekir. Bunun yam sıra;

Efendi derdi artar chl-i rütbe buldukca

Bakan derd-i ser-i erbāb-1 cāha pāyelerdür hep

beytinin vezni bozuk ilk mısranda, "ehl"den sonra iki heceli ve anlamı da tamamlayabilecek "mansıb", "devlet" ya da benzeri bir bașa kelime olmalıdır:

Efendi derdi artar chl-i [manșıb ] rütbe buldukç̣a 
İkinci mısradaki anlamsızlık ise, "Baḳan" kelimesinden ve tamlamadaki yanlışlıktan kaynaklanmaktadır. Bu mısraın da nüshalarda aşağıdaki gibi anlamlı bir şekli bulunmalıdır:

[Yı̀̇]an derd[i] ser-i erbāb-ı cāha pāyclerdür hep 356. sayfadaki;

Ġoncalar mānend-i aḩker hārlardur çūn şerer

Hurmen-i kül-i külhan pür-tāb olur sensiz baña

beytinin ikinci mısraı, vezin ve anlam gereği, aşağıdaki gibi okunmalıdır:

Hुirmen-i gül gülhhan-1 pür-tāb olur sensiz baña

Aynı sayfadaki ikinci beyitte geçen "kettān" kelimesi ise, vezin gereği "ketān" yazılmalıdır. Ayrıca;

Yār bī-raḥm u felek kec-rev u bahtum vardanh

Kạaldı iṣ Ḥaḳḳa dahı çāre-ger olmaz peydā

beyti;

Yār bì-raḥm u felek kec-rev ü bahtum [vārün]

Kaldı iṣ Ḥaḳḳa dahı çāre ger olmaz peydā

okunursa anlam kazanır. Bu sayfadaki tarih kıt'asının ilk beytinde de vezin bozuktur. Sayfa sonundaki beytin;

Oldı tekyc-i ḳavi bi-emri ilāh

mısraının, vezne uygun çevirisi şu șekilde yapılmalıdır:

Oldı tekye ḳavi be-emr-i İlāh

357. sayfadaki gazelin;

Gūyā dehen-i țabaḳçe-i rūy-ı nigārda

Memlū șarāb-1 gül ile piyāledür

beyti de hem anlamsız, hem de vezinsizdir. İlk misrai;

Gūyā dehen țabakçe-i rūy-1 nigārda

șcklinde yazarak vezin ve anlam bakımından düzcltebiliriz. İkinci mısradaki vezin bozukluğunun nedeni ise kelime eksikliğidir. Mısraın, aşağıda ayıraç içinde verdiğimiz kelimelerden birinin veya benzerinin yer aldığı nüshasının bulunabileceğini düşünmekteyiz:

Memlū șarāb-1 gül ile [rengīn / gülgūn]-piyāledür 358. sayfadaki;

Bir hōos nezāketle $\mathrm{Na}^{\prime}$ ìm al ayaginuñ 
mısranda vezin bozuktur. Mısraın, "bुosş" kelimesindeki transkripsiyon yanlıșı da düzeltilerek, vezne uygun yazımı;

Bir hyoş nezāket ile $\mathrm{Na}^{\prime}$ im al ayag̉uñı

olur. Ayrica;

Çoḳ ḳil ü ḳāl oldı miyānı-y-çūn ortada

Ḳaldı beli dinilmedi tã imtihạana dek

beytinin ilk mısraındaki "çūn" kelimesi vezin gereği "çün” olmalı; ikinci mısrandaki "Kaldı belī" ise, beyti doğru anlamlandırabilmek için "Ḳıldı beli" okunmalıdır. Bu sayfadaki beşinci beytin ilk musranda da vezin ve anlam bozuktur. Yine;

Eylerdi zinde olsalar ol șāh-1 bezm-i hiüsn

Fagfürī kāse-i çini vü sāḳi-i Sikenderi

beytinin ikinci mısraı vezinsiz ve anlamsızdır. Mısra, așağıdaki șckilde okunursa düzclecektir:

Fag̉fürı kāse-çini vü sāḳi Sikenderi

Böylecc beyit, "O güzellik bezminin şahı, yaşasalar(dı) Çin imparatorunu kâse toplayanı ve İskender'i saki(si) eylerdi." șeklinde ve anlamca doğru olarak nesre çevrilebilecektir. Yine;

Bu naẓm-1 pāk-sādeyi görse cy $\mathrm{Na}$ ìm

Teslim olurdı Hāfıze-1 Şirāzi vï Enveri beytinin çevriyazısı, vezin göz önünc alınarak, șöyle yapılmalıdır:

Bu naẓm-1 pāk-sādeyi görse[ydi] cy $\mathrm{Na}$ im

Teslīm olurdı Hāfız-1 Şirāzi Enveri

Bu ve 381. sayfadaki "ider" redifli gazelin;

Ṭaşt-1 simimin țutar șanma dilā vaḳt-i tırāş

Mihr-i rūyında küsūf-1 bुaț̣a nuz̧zăre ider

beytinin vezni ve anlam bozuk ikinci mısranı;

Mihr rūyında küsūf-ı hața nezzāăre ider

okumak gerekir. 359. sayfadaki kut'anun; ilk beytinin ikinci ve dördüncü beytinin ilk mısranda vezin bozuktur; üçüncü beytinin;

Oldı șer'i nebevỉ rāhına 'āzim-i cāzim

mısraının ise, anlam ve vezin bakımından doğru çevirisi şöyledir:

Oldı șer -i nebevỉ rāhına 'āzim càzim

361. sayfadaki;

Engüruñ çeșmüm göreli zchr-i dü-çeșmüñ 
Keyfiyyet-i mestī-i mey-i nābı unutdum beytinin ilk mısraındaki vezinsizlik ve anlamsızlığı, mısraı;

Engūrek-i çeşmüm göreli zehr-i dü-çeşmüñ

okuyarak düzeltebiliriz. Böylece beyti, "Gözbebeğim, senin iki gözünün zehrini göreli, (ben), saf şarabin sarhoşluğunun keyfiyetini unuttum." gibi anlamlı bir biçimde nesre çevirmek de mümkün olacaktır. Beşinci beytin;

Metā`-1 hüsni hiç șatma ey nev-reste rā'icdür mısra da vezinsizdir. Buradaki "hịç șatma" ifadesi, "yok pahasına vermek" anlamında "hiç̧e șatmak" deyiminin bulunduğu düşünülerek okunursa vezin de düzelecektir:

Metāe $^{-1}$ hüsni hịç [e] șatma ey nev-reste rā 'icdür 366. sayfadaki ikinci ve 383. sayfada üçüncü beyitteki "Hāy-1 hūy-1 şevḳ-i mihrüñ" tamlamasındaki "Hāy-1 hūy"un yazımı yanlıștır. Bu kelime, "mutlu ve sevinçli insanların șamatalarını dile getirmek için çıkardıkları ses" anlamındaki "Hāy-hūy" edatıdır. Bu nedenle tamlama "Hāy-hūy-1 şevk-i mihrüñ" yazılmalıdır. 367. sayfadaki ikinci beytin ilk misraı ile beşinci ve altıncı beyitlerin ikinci mısralarında vezin bozuktur. Sekizinci beytin;

Vāle-i şeydā-yı vaṣl olmıș idi çūnki o yār

mısraındaki anlamsızlığın nedeni "serap; ipek kumaş; inilti" anlamlarını taşıyan "Vāle" kelimesidir. Oysa bu kelime "şaşırmış, şaşkın, aşktan delirmiş" anlamında "Vālih" okunmalı ve bundan sonra bir de "ü" bağlacı yer almalıdır:

Dokuzuncu beytin;

Vālih [ü] şeydā-yı vaṣl olmış idi çünki o yār

Șun' ıma her mıșrā' indan geldi bir tārīh-bīn mısrandaki tārihh-bīn", anlam gereği "tārihh bīn" yazılmalıdır. 373. sayfadaki gazelin, soru işareti de konan;

Piçide hāle çūnki gerekir ? kākülüñ

mısraının, vezni ve anlamı göz önüne alarak, aşağıdaki gibi olabileceğini düşünmekteyiz:

Piçiide-[hāl] çünki girih-gīr kākülüñ

378. sayfadaki;

Ġam-1 ḳaddüñ bilmez tā bükülünce çekerüz 
okunan mısraının vezni ve anlamı bozuktur. Misra1;

Ġam-1 ḳaddüñ belümüz tā bükilince çekerüz

okuyarak hem vezni düzeltmek, hem de anlamlı hâle getirmek mümkündür.

Yazımızın son kısmında çevriyazısı verilen şiirlerde gördüğümüz bażı eksikliklere ișaret etmeye ve kimi zaman yanlışlıkları düzeltmeye çalıştıysak da, tam bir düzeltme yapmanın bütün nüshaları görmekle mümkün olacağını göz ardı etmemek gerekir. Zaten amacımız eserin doğru yanlış cetvelini çıkarmak değil, buraya aldıklarımızdan hareketle metinlerin doğru okunmasına katkıda bulunmaktır. Çünkü, dağınık durumdaki metinlerin bir araya getirilmesi ve çeşitli yönlerden incelenmesi suretiyle ortaya konulan çalışmaların araștırmacılara -gerek metinlere, gerekse konuya ilişkin bilgilere ulaşabilme konusunda- büyük kolaylıklar sağladığı açıktır. Ancak, araștırmacıların bu tür çalışmalardan yararlanmaları, özellikle de metin alıntıları yapabilmeleri, çevriyazısı verilen metinlerin bilimsel yöntemlerle azamî dikkat gösterilerek hazırlanmasına bağlıdır. Böyle bir dikkat, yapılan değerlendirmelerin sağlıklı olmasını ve çalışmaların da amacına ulaşmasını sağlayacaktır. Atlansoy'un, Bursa vefeyatnamelerinin bugüne kadar bilinmeyen nüshalarına ya da adı bilinmekle birlikte nüshası ele geçmemiş olanlarına ulaşmak ve bunları bilim dünyasına sunmak amacıyla hazırladığı çalışmasının yeni baskılarının gözden geçirilerek yapılmasını dileriz. 
İhsan S. Vasfi, Irak Türkleri'nde Deyimler ve Atasözleri, Kerkük Vakfi, 20x13, 264 Sayfa, İstanbul 2001

Kerkük Vakfı tarafından yayımlanan bu eserde, Irak Türklerinin kullandığı deyimler ve atasözleri bir araya toplanarak şimdiye kadar bu konuda yapılmış daha küçük çaplı çalışmaların geliş̧irilmesi sağlanmıştır. İçerik bakımından oldukça zengin olan eserin dış özellikleri de okuyucuların beğenisini kazanacak niteliktedir.

İhsan S. Vasfi, İzzettin Kerkük Kültür ve Araştırma Vakfı (Kerkük Vakfı) tarafından 2001 yılında yayımlanan kitabında, Irak Türkleri'nin kullandığı deyim ve atasözlerini bir araya toplamıştır. İlki 1985 yılında basılan kitap, 20x13 boyutlarındadır ve karton kapak üzerinde Kerkük kalesinin eski siyah beyaz bir fotoğrafı gölgelendirilerek kullanılmıştır.

Kitap iki bölümden oluşmaktadır. 1.Bölüm: Deyimler, 2.Bölüm: Atasözleri olarak düzenlenmiştir.

Giriş Bölümünde araştırmacı, atasözü ile deyimin daha önceki çalışmalarda karıştırıldığını, ancak bunların farklı şeyler olduğunu söyleyerek örnekler vermektedir. Pek az yerde deyimin atasözüne dayandığı görülmektedir. Örneğin: "Ballğı suda pazarlamak" deyiminin kaynağı "Balık suda pazarlanmaz" atasözüdür. Bu gibi deyimler alındıkları atasözlerinin anlamına benzer bir anlam taşıyorlarsa da bazen değişik bir anlam da taşıyabilirler. Örneğin: "Habbe habbe olur kubbe" tedbirli davranmakla az para veya maldan büyük bir miktar biriktirilir anlamındadır. Aynı atasözünden gelen "Habbeden kubbe etmek" deyimi ise, bir sözü veya bir işi büyütüp karıștırmak ya da abartmak anlamında kullanılır.

Deyimler bütün Türk dünyasında çok az farklarla aynı biçim ve kavramda söylenirken kimi zaman da tam tersi bir anlama karşı gelebilmektedirler: "Yağlı müssteri" Türkiye'de çok para harcayan müşteri demek iken, Irak Türkleri'nde bunun tersi yani alaycı biçimde çok inceleyip bir şey satın almayan müşteriyi ifade eder. Irak Türkleri'nde bir yeri ziyareti azaltmak anlamında "Ayak kesmek" deyimi kullanılırken, Türkiye'de "Ayağııı kesmek" veya "Ayağımı çekmek" kullanılır. Oysa Irak Türkleri'nde "Ayağını çekmek" birisini aldatmaya uğraşmak anlamına gelir. 
Bazen de deyimlerin ufak bir değişiklikle anlamının tamamen değiştiğine tanık oluruz: "Cana kıymak" deyimi öldürmek anlamını taşırken, "Cana mala kıymak" cömertlik göstermek anlamına gelir, "Göz kızartmak" öfkeyle bakmak anlamında iken, "Göz kızdırmak" azıcık uyumayı anlatır, "Dili bir karış olmak" fazla konuşmak, başkalarına sözle saldırmak anlamında iken, "Dili bir karış çıkmak" çok susamıș olmak anlamındadır. Görüldüğü gibi küçük sözcük değişiklikleri deyimlerin anlamlarında büyük sapmalar meydana getirmektedir. Bu da deyimleri günlük yaşantıda kullanmanın büyük bir hüner gerektirdiğini göstermektedir.

Eserde bazen tek sözcükten oluşan deyimlere de rastlanmaktadır. Örneğin: "Açılmak; l.Kimseye hissettirmeden bırakıp gitmek 2.Gönlündekini döküp söylemek ", "Adaklamak; Nișamlamak"

$\mathrm{Bu}$, araştırmacılar arasında tartışılmaya devam eden bir konudur. Ömer Asım Aksoy, "Atasözleri Sözlüğü" adlı eserinde:"İlk denemelerimde özel bir kavram anlatan kimi ekli sözcükleri ü̧̈üncü bir deyim türï sayıyordum "doğrusu" "sözde" "gözde"... gibi sözcükleri deyim olarak göstermistim. 1965'te yayımlanan Atasözleri ve Deyimler" adl k kitabımda deyimlerin en az iki sözcükle kurulacağını kabul ederek eski görüsüümü dïzelttim" demektedir. (Aksoy 1978: 38 -dipnot)

Doğan Aksan ise: "Belli bir kavram belli bir duygu ya da durumu dile getirmek için birden çok sözcüğün bir arada, seyrek olarak da tek bir sözcü̈ğün yan anlaminda kullanılmastyla oluşan sözdïr" demektedir. (Aksan 1995: 359)

Doğan Kaya ise bu tek sözcüklük deyimlere "yakıșırmma" terimini önermektedir.

Deyimlerin çoğu Irak Türkmen Türkçesinde isim fiil eki (mağ) yerine Türkiye Türkçesindeki (-mak/-mek) ile verilmiştir. Ancak değişik deyim formlarıyla da karşılaşılmaktadır. "Allah affetsin" gibi dua tarzında, "Allah așkma" gibi ünlem tarzında, "Aslan uğgı" "Ayakkabı" gibi birleșik isimlere araştırmacı ayak kabı sözcüğünü ayrı yazarak deyim saymıștır İmla klavuzunda bu sözcük bitişik gösterilmektedir.-, "Alm teri" gibi isim tamlamalarına ya da "Ağı söz" gibi sıfat tamlamalarına, "Arvad-kişi", "Bakkal çakkal" gibi ikilemelere -buradada yazar birinci örnekte araya tire koyarken 
ikinci örnekte buna gerek görmemiştir- veya "Aduv bağışla" gibi soru tarzlarına, "Ağzım açma" gibi emir şeklinde kullanımlara rastlanmaktadır. Olumlu ve Olumsuz şekilde çift kullanımı olan deyimler bir kez yazılıp olumsuzu tire ile gösterilmiştir. Örneğin: "Göz önünden kaybolmak- göz önünde tutmak"

Bir çok şekilli söylenebilen deyimler bir arada verilmiştir. Örneğin: "Geceyi gündüze katmak-bağlamak" "Birbirine girmekgeçmek- girișmek" Irak Türkmen ağzında yer alan kimi sözcüklerin Türkiye Türkçesindeki karşılıkları parantez içinde verilmiştir: "Gelin erkek, toy (düğün) battal", "Ay'a diyer (der) sen bat men çıhım (ben çıkayım)"

Eski bir folklor öyküsü ile ilgili olan, bir olaya dayanan deyimlerin öykü ve olayları en uygun olan rivayete göre yazılmıştır:

"Altunu (altini) yez, kattani (keteni) bez": Alay olarak başa kakma anlamında kullamilır. Ortasindan geçen Hassa Çayı Kerkük şehrini ikiye ayırır. Eskiden saka yollu iki semtin halkı birbirine karşı bazı alaylı sözler tekrarlarmış işte bu deyim Kale semti halkının Hassa Cayının karșisinda yer alan Koyrallara söyledikleri sözlerdendir ki, sonradan halk deyimleri arasına karıșmıștır.

Deyimlerin bazısı soru cevap şeklindedir: (git)"

"Adıv nedi (adın nedir) Gelebet, İșiv nedi (ișin nedir) gelip get

"Deveye dediler boynuv c gridi (boynun eğridir) dedi: haram düzdü? (nerem düzdür?)"

Bazı yöresel söyleyişler esere hareketlilik getirmiștir.

"Donguzdan bir tük (tüy) kupansa bile (koparsa bile) gene kârdı (kârdır)"

Irak Türkmen Türkçesi ağzındaki atasözlerini ele alan ilk eser Kerkük'ün ünlü şairlerinden Dede Hicri'nin 1928 yılında Kerkük'te basılan "Yadigari Hicri" adlı kitabında bulunan "Durub-i Emsal" başlıklı șiiridir. Bu șiirde atasözlerinin işlendiği görülür. Daha sonraları iki kitap daha basılmıștır: 1. Avukat Ata Terzibaşı'nın 
"Kerkük Eskilersözü", 2. .Şakir S.Zabit'in "Kerkük'te Hayat-l İctimaiye" Ayrıca Gazanfer Paşayev'in 1979'da Bakü'de yayımlanan "Irak Kerkük Atalar Sözleri" adlı kitabı sayılabilir. Bu kitaba da daha önce anılan iki kitap kaynaklık etmiştir.

Atasözleri anlamlarını açıkça ifade edebildiği için açıklamaya genel olarak gerek duyulmamıştır. İki veya bir kaç değişik biçimde söylenen aym anlamdaki atasózleri kitapta alfabe sırasına göre verilmiştir.

Örneğin: "İki karpuz bir koltuğa sıhılmaz(sığmaz)"

"Bir koltuğa iki karpuz sıhılmaz (sığmaz)"

"Sihılmaz bir koltuğa iki karpuz"

Nadiren atasözleri içindeki bazı sözcükler değişebilir. Bunlardan en yaygın olan önce yazılmış, ardından bașka tarzda olanlar tire arasına alınmıştır: olu (olur)"

Örneğin: "Kurt-aslan- kocalınca köpeklere mezzek (maskara)

Atasözleri yerli ağızda geçtiği gibi tesbit edilmiştir. Ancak konuşmada kullanılan sözcüklerin cümle içinde anlamları açık olsa da parantez içinde gösterilmiştir. Ayrıca değişik bir telaffuzla kullanılan sözcüklerin karşılığı verilmiştir.

Örneğin: "Arvadın (kadının) malı hamam dögecidi (tokacıdır)"

"Balığa piçah yohtu (bıçak yoktur)"

Bazen de sadece gereken ekler belirtilmiştir. Örneğin: "Alah dağına göre kar yağdırı (...rır)"

Atasözlerinde yerini koruyup, günlük konuşmada kullanılmayan bazı sözcüklere rastlanabilir.

Örneğin: "Tarı (Tanrl) zeğele (kurnaza) vermez." Tanrı sözcügüi artık konuşma dilinde kullanımamaktadır.

Eser, Anayurda çok yakın olmakla beraber, ondan ırak düșmüș insanların düşünce dünyalarnı geçmişten yarınlara taşıyan çok değerli bir kaynaktır. Araştırmacıyı kutluyor, böyle bir eseri çok güzel bir baskıyla okurlarına sunan Kerkük Vakfına teşekkür ediyoruz. 


\section{Kaynakça}

Aksoy, Ömer Asım, Atasözleri Sözlüğü I, TDK Yayınları., Ankara 1978, s.38 dipnot.

Aksan, Doğan, Her Yönüyle Dil, Ana Çizgileriyle Dilbilim TDK Yayınları No:439, Ankara 1995.

Dr. Fatma Sibel Bayraktar ${ }^{*}$

*Trakya Üniversitesi Fen-Edebiyat Fakültesi Türk Dili ve Edebiyatı Bölümü Araștırma Görevlisi. 